\title{
APSA Announces New Editorial Team for the Journal of Political Science Education
}

$\Lambda$ PSA has announced a new editorial team for the Journal of Political Science Education. After an intensive national search for the next editorial team, APSA selected a team of six editors, led by Victor Asal, University at Albany. The editorial team includes Mitchell Brown, Auburn University; Mark L. Johnson, Minnesota State Community and Technical College; Joseph W. Roberts, Roger Williams University; Shane Nordyke, University of South Dakota; and J. Cherie Strachan, Central Michigan University.

"This team includes a highly experienced editorial team who brings together impressive breadth and depth of experience in the Scholarship of Teaching and Learning (SoTL)," noted the search committee in its recommendation to the APSA Council. Furthermore, the new team has proposed to reorganize the journal-building on its current success-into four substantive sections: "Scholarship of Teaching and Learning," "Political Science Instruction," "Reflections on Teaching and the Academy," and "Books, Teaching Tools, and Educational Resources."

"We plan to build on the accomplishments of the past editors while widening the audience and the areas of pedagogy that do not find an editorial home elsewhere," explained Victor Asal, the editor in chief. "We will strive to make the journal inclusive of the entire profession, appealing to professors, instructors, and graduate students at research institutions, comprehensive universities, liberal arts colleges, and community colleges"

APSA President Jennifer Hochschild noted, "We very much look forward to working with this editorial team to build the journal's visibility and importance to the discipline and to all of our members."

APSA Executive Director Steven Rathgeb Smith highlighted the team's inclusion of highly experienced SoTL faculty from a diverse range of institutions. "This combination provides compelling evidence of their commitment to creating a representative and inclusive discipline-wide journal of political science education," he said.
The appointment follows on the recent change in structure of the journal. In September 2015, the APSA Organized Section on Political Science Education voted to support the shift in sponsorship from the section to APSA. This change also includes providing online subscriptions to all APSA members in January 2017, thereby increasing readership and visibility of the journal and political science education. The journal is owned and published by Taylor \& Francis.

For more information visit Visit http:// www.apsanet.org/jpse.

\section{Editorial Team}

\section{EDITOR IN CHIEF}

\section{Victor Asal}

Victor Asal (Editor in Chief) is chair of the Department of Public Administration and an associate professor in the Department of Political Science at the Rockefeller Col-

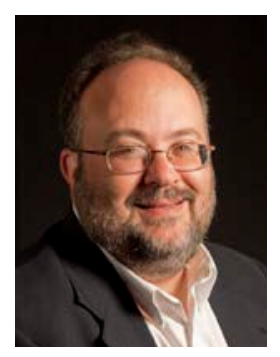

lege, University at Albany SUNY.Asal's research focuses on political violence, political discrimination, and the use of simulations as a tool of teaching in political science. He has been involved in Active Learning in International Affairs section (ALIAS) of the International Studies Association and the Organized Section on Political Science Education of American Political Science Association (APSA) and has been the program chair for the APSA Teaching and Learning Conference (TLC). At both the ISA and APSA annual meetings, he has conducted workshops about using and creating simulations, and he has published articles on simulations in International Studies Perspectives, and the Journal of Political Science Education. He has received the Deborah Gerner Innovative Teaching in International Studies Award presented by the ISA and the CQ Press Award for Teaching Innovation awarded at the APSA's TLC.

\section{SCHOLARSHIP OF TEACHING AND LEARNING SECTION \\ Mitchell Brown}

Mitchell Brown (Coeditor) is a professor in the department of political science at Auburn University and serves as the director of its $\mathrm{PhD}$ program in public administration and public policy. Her broader research

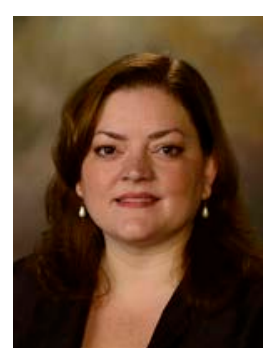

agenda focuses on the empowerment efforts of marginalized communities, which she pursues particularly through applied research. In addition, she is interested in pedagogy related to teaching research methods. She is the recipient of numerous awards, including the Auburn University Student Government Outstanding Faculty Award for the College of Liberal Arts for 2016 and 2013. She is the author of numerous books, research articles, and reports, including her two most recent books, Administering Elections: How American Elections Work with Kathleen Hale and Robert Montjoy and Applied Research Methods in Public and Non-Profit Organizations, also with Kathleen Hale.

\section{Shane Nordyke}

Shane Nordyke (Coeditor) is associate professor of political science at the University of South Dakota, where she also serves as the Director of the Government Research Bureau. She primarily teaches courses on

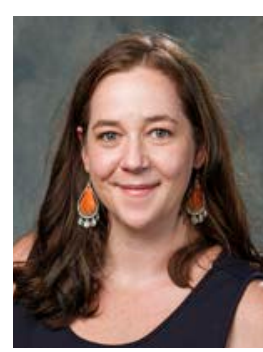
public policy and research methods in the departments und ergraduate, MPA, and PhD programs. Her research focuses heavily on applied research with state and local partners through the government research bureau, particularly in the areas of public safety, highway safety, and homeland security. She also continues to do research on the scholarship of teaching 
and learning within political science. In 2010, she served as a lead developer for the NSF supported Online Portal of Social Science Education in Methods (OPOSSEM) and has served as the president of the Great Plains Political Science Association.

\section{POLITICAL SCIENCE INSTRUCTION SECTION}

\section{Joseph W. Roberts}

Joseph W. Roberts (Editor) is an associate professor of politics and international relations and a 2010 Presidential Fellow at Roger Williams University (RWU) in Bristol, Rhode Island. Roberts is an inau-

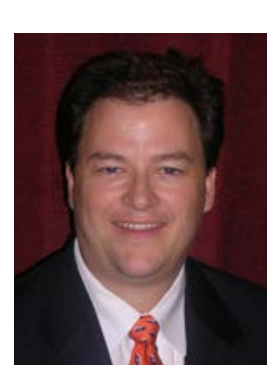
gural Alwaleed Fellow for Oman for the National Council on US-Arab Relations (2015-2016). He was also a member of the RWU FulbrightHayes Egypt Fellowship in July 2011. He is currently the treasurer of the Organized Section on Political Science Education of the American Political Science Association. Roberts book, How the Internet Is Changing the Practice of Politics in the Middle East: Political Protest, New Social Movements, and Electronic Samizdat, was published in 2009 from Edwin Mellen Press. He has published in European Political
Science, PS: Political Science and Politics, and Periodica Islamica.

\section{REFLECTIONS SECTION}

Mark L. Johnson

Mark L. Johnson (Editor) is an instructor (with tenure) of political science and history at Minnesota State Community and Technical College in Moorhead, Minnesota. He is a former program committee

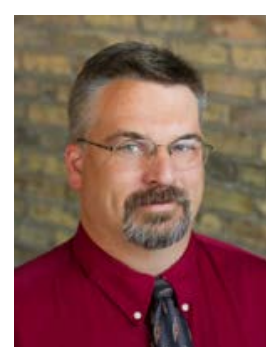
member and chair for the APSA Teaching and Learning Conference (TLC) and has participated in eight of the TLCs as a presenter, track moderator, discussant, and workshop facilitator. He has served as co-chair of a major overhaul of the campus Academic Plan (including a redesign of the Associate of Arts degree) and chair of the college's Curriculum Committee. He currently serves on the executive board of the Minnesota Political Science Association, as well as the program committee for the Great Plains Political Science Association's Annual Conference. A former Chief Clerk of the North Dakota House of Representatives, he is a frequent commentator in Fargo-Moorhead media on local and regional politics and elections.
BOOKS, TEACHING TOOLS, AND

EDUCATIONAL RESOURCES

SECTION

\section{J. Cherie Strachan}

J. Cherie Strachan (Editor) is director of student and civic engagement for the College of Humanities, Social and Behavioral Sciences, and professor of political science at Central Michigan University. She is the

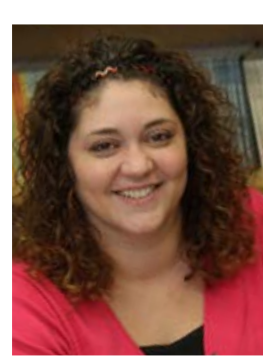
author of High-Tech Grassroots: The Professionalization of Local Elections, as well as numerous articles and book chapters. Her recent publications focus on the role of civility in a democratic society, as well as on college-level civic education interventions intended to enhance students' civic skills and identities. Her applied research, which focuses on facilitating student-led deliberative discussions sessions and on enhancing campus civil society, has resulted in on-going work with the Kettering Foundation. She is also the co-founder of the Consortium for Inter-Campus SoTL Research (CISR), which facilitates cross-campus data collection for campus-wide civic engagement initiatives and political science pedagogy research.

\section{CALL FOR SUBMISSIONS FOR SPECIAL ISSUE OF JPSE: DEALING WITH EXPLOSIVE ISSUES IN TODAY'S CLASSROOM}

Teaching political science can be challenging for many reasons. We often discuss topics that students have a vested interest in, subjects that can be very upsetting for some students, or topics about which students may vociferously disagree. For this special issue of the Journal of Political Science Education, we are looking for submissions (systematic quantitative or qualitative studies, case studies, or reflections) that investigate how political science educators can deal with a variety of explosive issues that arise in classroom discussions as well as explosive issues that are at the core of syllabi in political science. Specifically, we are looking for manuscripts that focus on novel, effective approaches to these issues as well as how educators deal with challenges as they arise organically in class related to:

- Teaching about race, sex, gender, and discrimination

- Teaching in contentious political times

- Teaching about when our methods go awry (or show unexpected results)

- Teaching during time of fear

If you are interested in submitting a manuscript, or have questions or suggestions, please contact the editors at jpse@apsanet.org. 